\title{
EFFECT OF WASTE TEA (CAMELLIA SINENSIS) WOOD FIBERS AND MAPE ON SOME PROPERTIES OF HIGH DENSITY POLYETHYLENE (HDPE) BASED POLYMER COMPOSITES
}

\author{
İlkay ATAR ${ }^{1 *}$, İbrahim Halil BAŞBOĞA ${ }^{2}$, Kadir KARAKUS ${ }^{1}$, Fatih MENGELOGLU ${ }^{1}$ \\ ${ }^{1 *}$ Faculty of Forestry, Dept. of Forest Industry Engineering, KSÜ, Kahramanmaraş, 46050, Turkey \\ ${ }^{2}$ Wood Product Industry Engineering Department, Kutahya Dumlupinar University, 43500 Kutayha, Turkey \\ *Corresponding author: iatar@ksu.edu.tr
}

İlkay ATAR: https://orcid.org/0000-0001-9527-1791

İbrahim Halil BAŞBOĞA: https://orcid.org/0000-0002-3272-7269

Kadir KARAKUȘ: https://orcid.org/0000-0001-7088-4364

Fatih MENGELOĞLU: https://orcid.org/0000-0002-2614-3662

Please cite this article as: Atar İ., Başboğa İ. H., Karakuş K., Mengeloğlu F. (2021) Effect of Waste Tea (Camellia Sinensis) Wood Fibers and MAPE on Some Properties of High Density Polyethylene (HDPE) Based Polymer Composites, Turkish Journal of Forest Science, 5(2), 606-619

\section{ESER BILGISI / ARTICLE INFO}

Araştırma Makalesi / Research Article

Geliş 14 Eylul 2021 / Received 14 September 2021

Düzeltmelerin gelişi 14 Nisan 2021 / Received in revised form 14 April 2021

Kabul 20 Ekim 2021 / Accepted 20 October 2021

Yayımlanma 31 Ekim 2021 / Published online 31 October 2021

\begin{abstract}
The objective of this study was to investigate the utilization of waste tea wood fibers (WTWF) and effect of maleic anhydride treated polyethylene (MAPE) in thermoplastic composites. For this purpose, HDPE as matrix, WTWF as lignocellulosic filler and MAPE as coupling agent were used. Six different composites were produced by injection molding method; 0-15-30\% WTWF filler ratio, with MAPE and without MAPE. The physical, mechanical, thermal and morphological properties of composite materials were determined. As a result, tensile strength, tensile modulus, flexural strength and flexural modulus of the composites were increased with the rise of the WTWF amount in the thermoplastic matrix. However, WTWF increase in the thermoplastic matrix reduced the elongation at break and impact strength of the produced composites. Addition of MAPE in thermoplastic matrix improved tensile strength, flexural strength and flexural modulus of manufactured composites. In the case of thermal properties, addition of WTWF into the thermoplastic matrix increased the char rate of the composites. However, the initial degradation did not change. It appears that waste tea wood fibers may have a potential usage as filler in the HDPE-based thermoplastic composites.
\end{abstract}

Keywords: Wood- plastic composite, lignocellulosic material, chemical analysis of waste tea wood, Camellia Sinensis, injection molding. 


\section{YÜKSEK YOĞUNLUKLU POLİETILEN BAZLI POLIMER KOMPOZITLERIN BAZI ÖZELLIKLERİ ÜZERINE ATIK ÇAY ODUNU LIFLERI VE MAPE'NIN ETKISI}

ÖZET: Bu çalışmanın amacı termoplastik kompozitlerde atık çay odunu liflerinin kullanımı ve maleik anhidritle muamele edilmiş polietilenin etkisini araştırmaktır. $\mathrm{Bu}$ amaç doğrultusunda, matris olarak yüksek yoğunluklu polietilen (HDPE), lignoselülozik dolgu maddesi olarak atık çay odunu lifleri (WTWF) ve uyumlaştırıcı olarak da maleik anhidritle muamele edilmiş polietilen (MAPE) kullanılmıştır. Enjeksiyon kalıplama yöntemiyle \%015-30 oranlarında WTWF dolgu maddesi ile MAPE'li ve MAPE'siz olmak üzere altı faklı kompozit üretilmiştir. Kompozit malzemelerin fiziksel, mekanik, termal ve morfolojik özellikleri belirlenmiştir. Sonuç olarak, termoplastik matriste WTWF oranını artması ile kompozitlerin çekme direnci, çekmede elastikiyet modülü, eğime direnci ve eğilmede elastikiyet modülü değerleri yükselmiştir. Fakat termoplastik matriste WTWF'in artması kompozitlerin kopmada uzama ve darbe direnci değerlerini azaltmıştır. Termoplastik matrise MAPE'nin eklenmesi ile kompozitlerin çekme direnci, eğilme direnci ve eğilmede elastikiyet modülü değerleri yükselmiştir. Termal özelliklere bakıldığında termoplastik matrise WTWF eklenmesi ile kompozitlerin kömür oranı artmıştır. Fakat başlangıç bozunma derecesi değişmemiştir. Atık çay odunu liflerinin HDPE bazlı termoplastik kompozitlerde dolgu maddesi olarak potansiyel bir kullanıma sahip olabileceği görülmektedir.

Anahtar kelimeler: Odun-plastik kompozit, lignoselülozik materyal atık çay odunu kimyasal analizi, Camellia Sinensis, enjeksiyon kalıplama.

\section{INTRODUCTION}

Wood-plastic composites (WPC) are materials which consist of thermoplastic polymer as matrix, wood flour as lignocellulosic filler and additives. Many investigators study on using annual plant wastes in WPC as an alternative to wood in recent years. Annual plant and agriculture wastes such as rice husk, wheat straw, hazelnut shell, corn cob, cotton husk, bananas stalk, flax straw, luff a fiber, kenaf, corn stalks, bagasse are important filler materials used for wood-plastic composite manufacturing. Their advantages can be listed as availability in large amount, annual renewability, low cost, lightweight, reduced energy consumption, and environmentally friendliness (Stark and Rowlands, 2003; Demir et al., 2006; Panthapulakkal and Sain, 2007; Yao et al., 2011; Mengeloğlu and Karakus, 2008; Liu et al., 2009).

Tea is one of the most important agricultural products in Turkey. Turkey, which ranks 7th in the world in terms of the width of tea agricultural areas, ranks 5th in dry tea production. Tea cultivation is carried out on an area of approximately 785,693 decares in Turkey. In order to increase the quality of tea, 1/5 of the tea gardens are pruned every year (Tea sector report, 2019). Thus, approximately 157,138 decares of land are pruned every year. As a result, large amount waste tea woods are occurred. These pruning wastes are either burned in the field or left on soil by farmers.

Although there are several studies on the use of many annual plant and agricultural wastes, on utilization of waste tea wood fibers have not been investigated extensively. The aim of this study is to evaluate the effect of waste tea wood fibers (WTWF) and MAPE on physical, 
mechanical, thermal and morphological properties of high density polyethylene based polymer composites.

\section{MATERIALS AND METHODS}

\section{Materials}

Waste tea wood fibers (WTWF) as filler and high density polyethylene (HDPE) as a polymeric matrix were used. In additionmaleic anhydride-grafted polyethylene as a coupling agent were used. HDPE was supplied Petkim Petrochemical Company in Turkey. WTWFs were provided from the local farmers in Rize/Turkey. These were granulated into fiber form using a Wiley mill and dried. Then, fibers screened and retained on 60 mesh-size screen, were used for manufacturing composite.

\section{Chemical Analysis of Waste Tea Wood Fiber}

Chemical analysis of WTWF were done according to TAPPI Standard Method T 257-os-76. Alcohol-benzene solubility, hollocellulose, alpha cellulose, cellulose, and lignin amount of WTWF were determined in accordance with TAPPI T $204 \mathrm{~cm}-97$, Wise's chloride method $^{18}$, TAPPI T $203 \mathrm{~cm}-71$, TAPPI T $203 \mathrm{~cm}-99$, TAPPI T $222 \mathrm{~cm}-\mathrm{O} 2$, respectively. All measurements were repeated three times.

\section{Composite Manufacturing}

The composition of produced composites is shown in Table1. Composites were manufactured in six different combinations. Composites were produced using injection molding methods.

WTWFs, HDPE and MAPE or without MAPE were mixed, speed range 5-1000 rpm, for 5 min. The compounding was accomplished using a laboratory scale single screw extruder. The temperature was set to $170{ }^{\circ} \mathrm{C}, 175{ }^{\circ} \mathrm{C}, 180{ }^{\circ} \mathrm{C}, 185^{\circ} \mathrm{C}$, and $190{ }^{\circ} \mathrm{C}$ for five heating zones. Produced pellets were cooled in water and granulated. Granulated pellets were dried in the oven. These pellets then were injection moulded to produce the test samples. The temperature of injection moulding machine was $180-200{ }^{\circ} \mathrm{C}$ from feed to die zone. After produced tests samples were conditioned in a climatic room with the temperature of $20{ }^{\circ} \mathrm{C}$ and the $65 \%$ of relative humidity.

Density, tensile, flexural and impact strength values of test samples were determined according to ASTM D 792 ASTM D $638(5.0 \mathrm{~mm} / \mathrm{min})$, ASTM D $790(2.0 \mathrm{~mm} / \mathrm{min})$ and ASTM D 256, respectively.

Thermal properties of samples were investigated by Thermogravimetric Analysis (TGA). All samples were performed under the dynamic nitrogen of a flow rate at $20 \mathrm{~mL} / \mathrm{min}$ using a heating rate of $20^{\circ} \mathrm{C} / \mathrm{min}$ from room temperature to $800^{\circ} \mathrm{C}$. 
Table 1: The Composition of WTWF Filled Thermoplastic Composites

\begin{tabular}{cccc}
\hline Specimen ID & $\begin{array}{c}\text { Usage HDPE } \\
\text { rate (\%) }\end{array}$ & $\begin{array}{c}\text { Waste Tea Wood } \\
\text { Fiber Loading (\%) }\end{array}$ & $\begin{array}{c}\text { Usage MAPE } \\
\text { rate (\%) }\end{array}$ \\
\hline Control_HDPE & 100 & 0 & 0 \\
Control_HDPE+MAPE & 97 & 0 & 3 \\
WTWF1 & 85 & 15 & 0 \\
WTWF2 & 82 & 15 & 3 \\
WTWF3 & 70 & 30 & 0 \\
WTWF4 & 67 & 30 & 3 \\
\hline
\end{tabular}

Scanning electron microscopy (ZEISS EVO LS 10) was used to determine morphologic property of produced samples. The samples were first dipped into liquid nitrogen and snapped to half to prepare the fractured surfaces. The fracture surface of samples was prepared by sputtering with gold.

Table 2: Chemical Composition of Waste Tea Wood Fiber

\begin{tabular}{lc}
\hline Chemical Composition & \% \\
\hline Hollocellulose & 77,09 \\
Cellulose & 47,18 \\
Alpha cellulose & 53,55 \\
Lignin & 28,94 \\
Alcohol benzene solubility & 0,89 \\
\hline
\end{tabular}

\section{RESULTS AND DISCUSSION}

The results of chemical analysis of WTWFs are presented in Table 2. Tea (Camellia Sinensis) is a perennial in bush form. Chemical components of tea wood are similar to that of hardwood trees.

Table 3: Density Values of Sample Groups

\begin{tabular}{cc}
\hline Specimen & $\begin{array}{c}\text { Density value } \\
\left(\mathbf{g r} / \mathbf{c m}^{\mathbf{3}}\right)\end{array}$ \\
\hline Control_HDPE & 0,952 \\
Control_HDPE+MAPE & 0,946 \\
WTWF1 & 0,979 \\
WTWF2 & 0,994 \\
WTWF3 & 0,981 \\
WTWF4 & 1,001 \\
\hline
\end{tabular}

Table 3 show density values of manufactured samples. Statistical analysis showed that both WTWF loading and addition of MAPE had a significant effect on density values. Interaction graph of density values was presented in Figure 1. X axis denoting the WTWF amount (\%) while $\mathrm{Y}$ axis shows measured properties. Red and green shapes present without MAPE samples and MAPE samples, respectively. The density values were increased with the rising of WTWF loading and addition of MAPE in the matrix. There was also an interaction between fiber loading and addition of MAPE. 


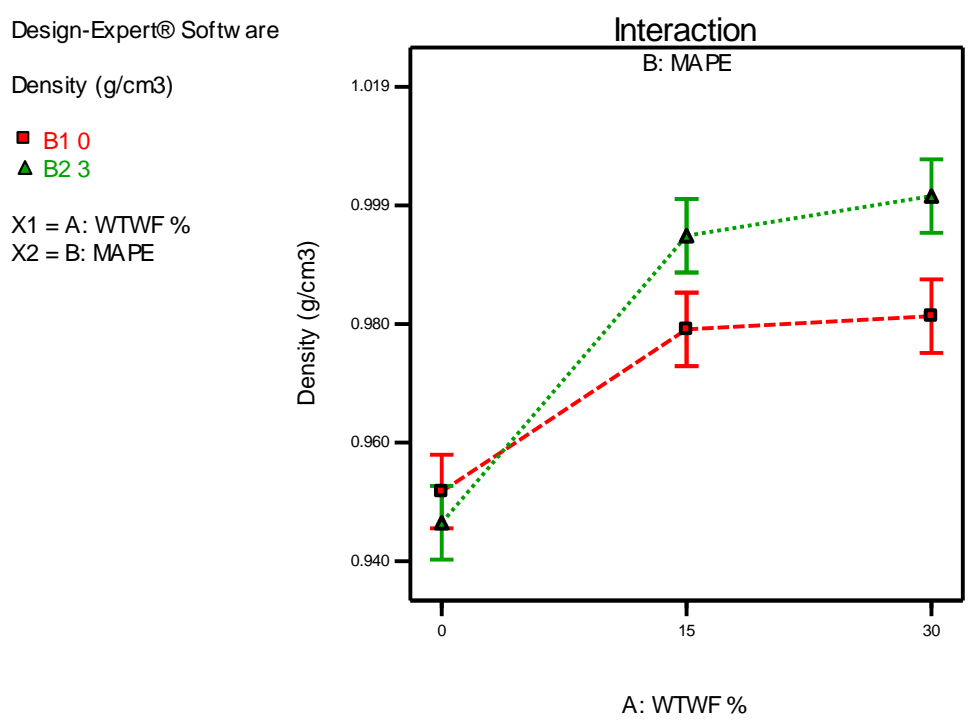

Figure 1: Interaction Graph of WTWF Loading and Addition of MAPE on Density Value

Mechanical values are shown in Table 4. Tensile properties include tensile strength, tensile modulus, and elongation at break.

The interaction graph of tensile strength was presented in Figure 2. Statistical analysis showed that increasing of WTWF loading and addition of MAPE had a significant effect on tensile strength $(\mathrm{P}<0.0001)$. There was also an interaction between fiber loading and addition of MAPE $(\mathrm{P}<0.0001)$. The tensile strength values of samples were increased with the rising of WTWF loading. The reason for this may be that the waste tea wood fibers are thin and long (Figure 10.g). Furthermore, addition of MAPE in the matrix increased also the tensile strength values of samples. This fact is because MAPE improved adhesion between wood and plastic (Coutinho et al., 1998; Sombatsompop, 2005; Wang et al., 2003).

Table 4: Mechanical Properties of Waste Tea Wood Fiber Filled Composites

\begin{tabular}{ccccccc}
\hline Specimen ID & $\begin{array}{c}\text { Tensile } \\
\text { strength } \\
(\mathbf{M P a})\end{array}$ & $\begin{array}{c}\text { Tensile } \\
\text { modulus } \\
\mathbf{( M P a )}\end{array}$ & $\begin{array}{c}\text { Elongation } \\
\text { at break } \\
\mathbf{( \% )}\end{array}$ & $\begin{array}{c}\text { Flexural } \\
\text { strength } \\
(\mathbf{M P a})\end{array}$ & $\begin{array}{c}\text { Flexural } \\
\text { modulus } \\
\mathbf{( M P a )}\end{array}$ & $\begin{array}{c}\text { Impact } \\
\text { strength } \\
\left(\mathbf{k j} / \mathbf{m}^{\mathbf{2}} \mathbf{)}\right.\end{array}$ \\
\hline Control_HDPE & 22,05 & 347,35 & 450 & 25,92 & 803,882 & 5,27 \\
Control_HDPE+MAPE & 21,94 & 333,83 & 450 & 25,59 & 864,56 & 4,56 \\
WTWF1 & 22,63 & 601,81 & 9,83 & 33,03 & 1266,12 & 4,84 \\
WTWF2 & 25,95 & 628,41 & 8,23 & 36,17 & 1314,41 & 4,32 \\
WTWF3 & 23,66 & 869,77 & 4,52 & 42,45 & 2239,76 & 3,78 \\
WTWF4 & 28,04 & 906,54 & 4,94 & 48,97 & 2337,65 & 3,88 \\
\hline
\end{tabular}




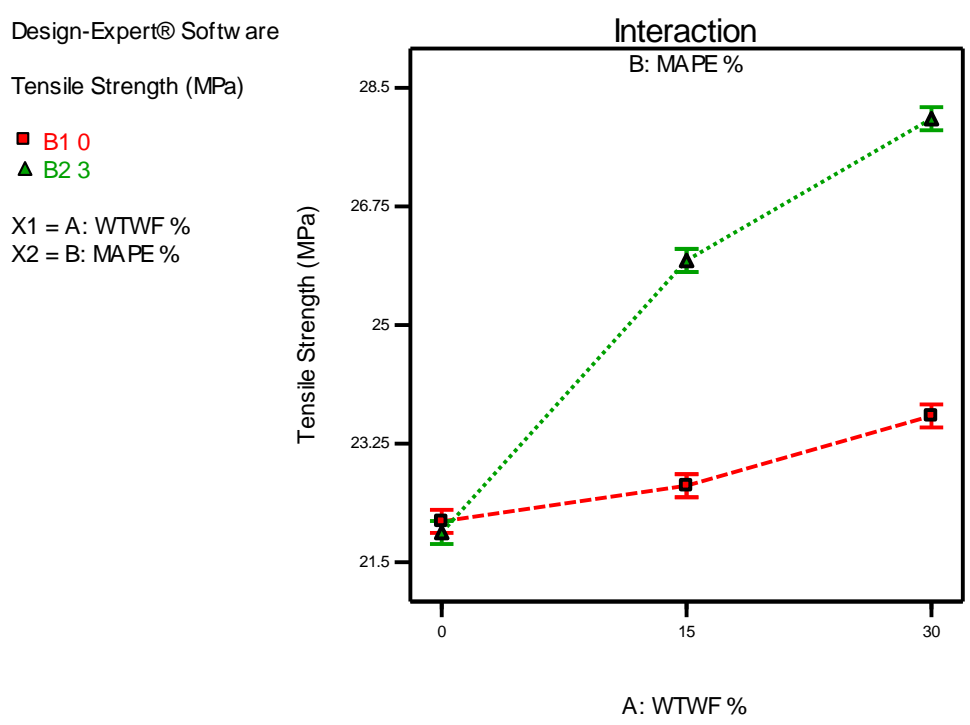

Figure 2: Interaction Graph of WTWF Loading and Addition of MAPE on Tensile Strength

The amount of WTWF loading in the matrix had a significant effect on tensile modulus $(\mathrm{P}<0.0001)$. However, addition of MAPE had not a significant effect on tensile modulus. Figure 3 shows the interaction graph of tensile modulus. The tensile modulus values of samples were increased with the rising of WTWF loading in the polymer matrix. This is because wood or lignocellulosic materials have higher modulus than thermoplastic polymer matrix. Similar results at other studies in literature were also reported (Mengeloglu and Kabakci, 2008; Klyosov, 2007; Stark and Berger, 1997; La Mantia et al., 2005; Nunez et al., 2002).

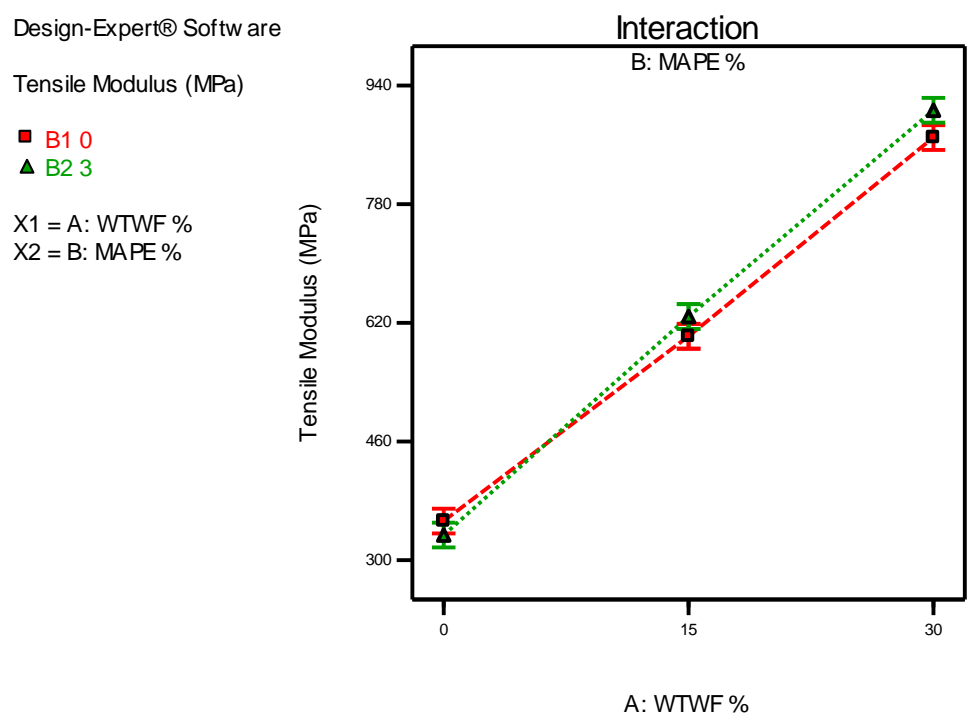

Figure 3: Interaction Graph of WTWF Loading and Addition of MAPE on Tensile Modulus

Interaction graph of elongation at break was presented in Figure 4. Based on the statistical analysis, both amount of WTWF loading and addition of MAPE had a significant effect on elongation at break values. The elongation at break values of samples were decreased with 
the rising of WTWF loading in the polymer matrix. This is because manufactured composites became stiffer with rising of WTWF loading and addition of MAPE. Elongation at break values decrease usually with increased modulus in composites (Chan and Balke, 1997; Sain and Panthapulakkal, 2006).

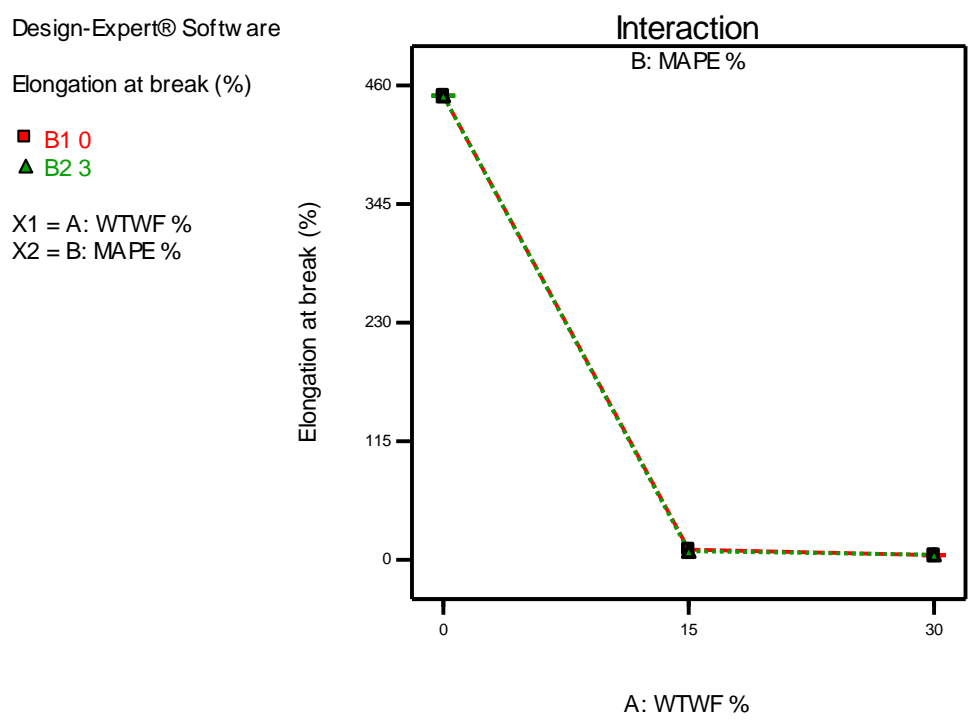

Figure 4: Interaction Graph of WTWF Loading and Addition of MAPE on Elongation at Break

The interaction graph of flexural strength was shown in Figure 5. Statistical analysis showed that both WTWF loading and addition of MAPE had a significant effect on flexural strength $(\mathrm{P}<0.0001)$. The flexural strength values of samples were increased with the rising of WTWF loading and addition of MAPE in the matrix. Similar to tensile strength, the reason for this may be that the wood fibers are thin and long, and that MAPE improved adhesion between wood and plastic ( Yang et al, 2007; Li and Matuana, 2003; Lai, 2003). For polyolefin-based plastic lumber decking boards, ASTM D 6662 (2001) standard requires the minimum flexural strength of $6.9 \mathrm{MPa}$. The tested all samples provided the requirements of ASTM D 6662.

Interaction graph of flexural modulus was presented in Figure 6. Similar to flexural strength, both amount of WTWF loading and addition of MAPE had a significant effect on flexural modulus $(\mathrm{P}<0.0001)$. The flexural modulus values of samples were increased with the rising of WTWF loading and addition of MAPE in the polymer matrix. The reason of flexural modulus increases is because natural fibers have higher modulus than polymer matrix (Chaharmahali et al., 2010). ASTM D 6662 (2001) standard requires the minimum flexural modulus of $340 \mathrm{MPa}$. All composites provided the requirements of standards. 


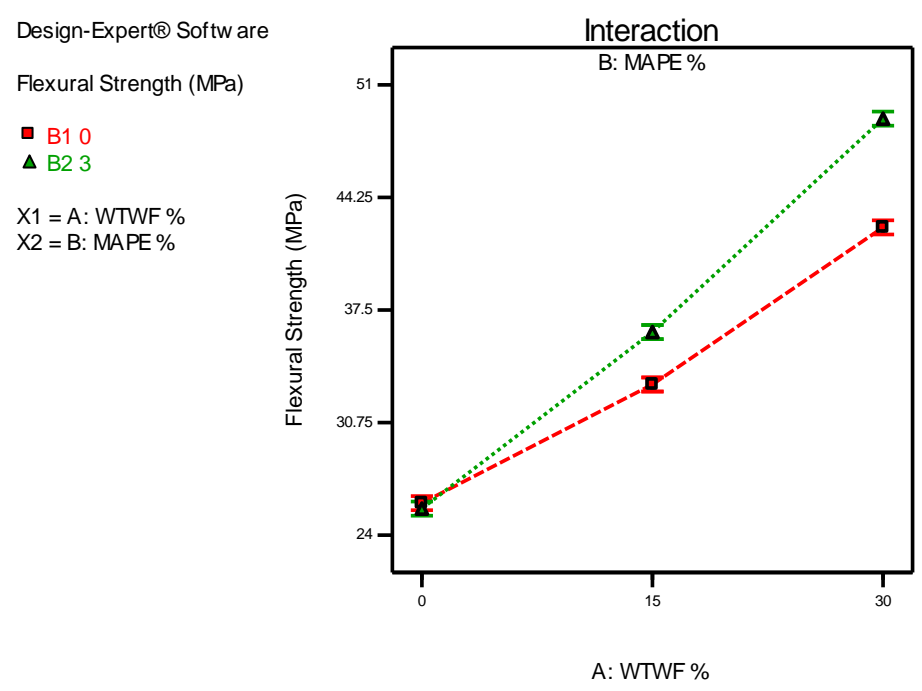

Figure 5: Interaction Graph of WTWF Loading and Addition of MAPE on Flexural Strength

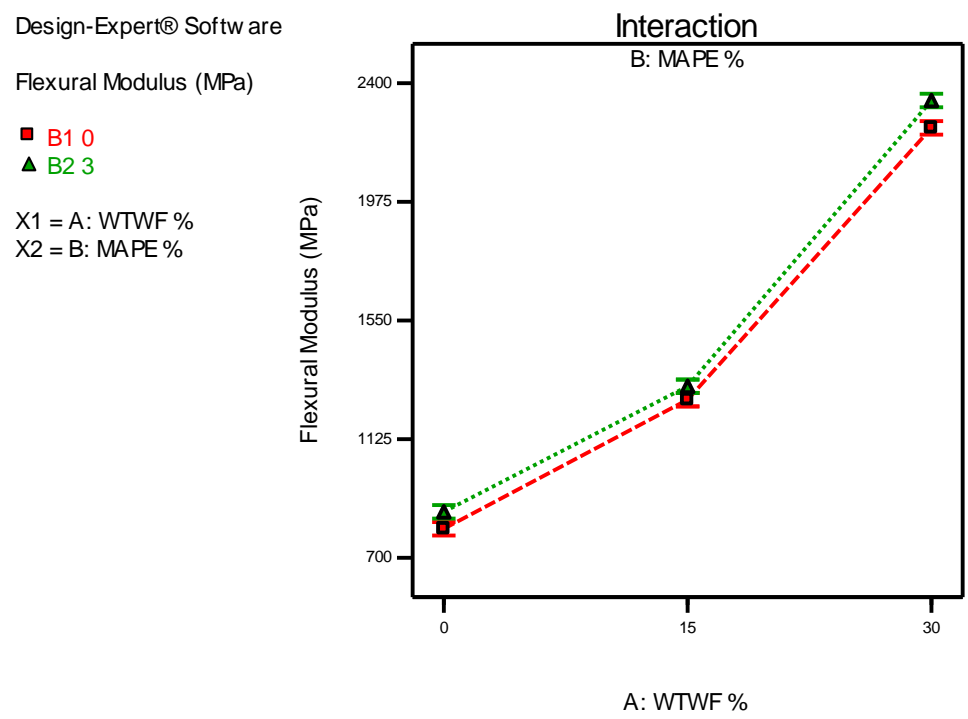

Figure 6: Interaction Graph of WTWF Loading and Addition of MAPE on Flexural Modulus

The interaction graph of impact strength was shown in Figure 7. Statistical analysis showed that WTWF loading and addition of MAPE had a significant effect on impact strength. The impact strength values of samples were decreased with the rising of WTWF loading and addition of MAPE in the polymer matrix. The reason of impact strength decreases is due to increase of brittleness of composite with the fiber increases in polymer-matrix (Mengeloglu and Karakus, 2008; Li and Matuana, 2003; Mengeloglu et al., 2000). 


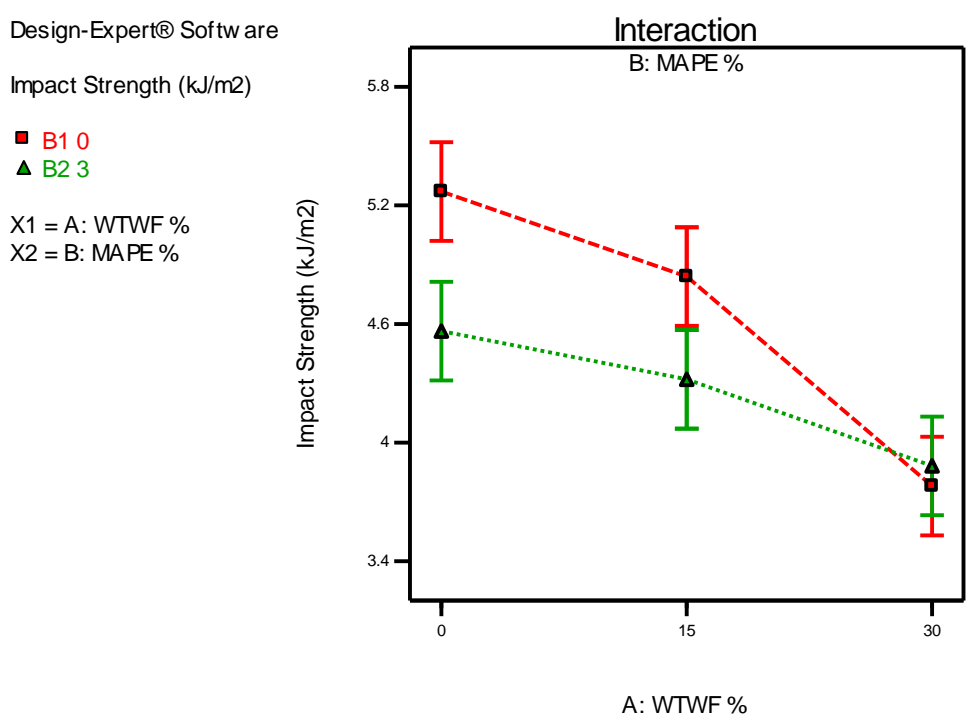

Figure 7: Interaction Graph of WTWF Loading and Addition of MAPE on Impact Strength

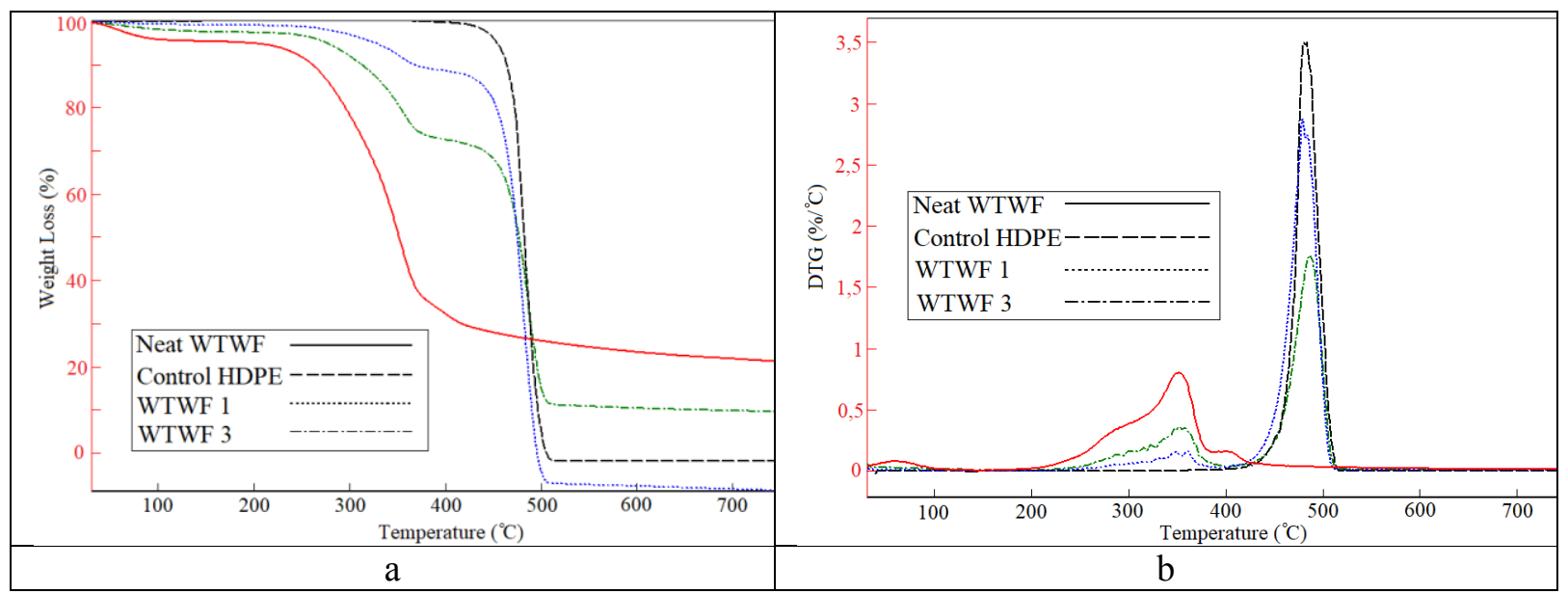

Figure 8: (a) TGA Thermographs of Neat WTWF, WTWF Filled HDPE and Control (unfilled) HDPE Thermoplastic Composites; (b) DTG Thermographs of Neat WTWF, WTWF Filled HDPE and Control (unfilled) HDPE Thermoplastic Composites.

Figure 8 and 9 show the TGA thermographs and derivative thermogravimetry (DTG) curves of the specimens. TGA curves show weight loss during increasing temperature while DTG curves show the speed of weight loss during thermal stability. The onset degradation of neat WTWF was started at around $185^{\circ} \mathrm{C}$ with a weight loss $95.16 \%$ while the HDPE based specimens were started above $445^{\circ} \mathrm{C}$ (Figures 8 and 9).

Table 5 gives the results of onset decomposition, max DTG curves and residue at $500^{\circ} \mathrm{C}$ during thermal stability. The highest max DTG degradation temperature was obtained from the WTWF 2 and WTWF $4\left(490^{\circ} \mathrm{C}\right)$. The neat WTWF had two peaks with the values $354^{\circ} \mathrm{C}$ and $400^{\circ} \mathrm{C}$ (Figures 8 and 9). It is known that wood consist of than hemicellulose, cellulose and lignin. Cellulose, hemicelluloses and lignin degradation interval $248-350^{\circ} \mathrm{C}, 150-350^{\circ} \mathrm{C}$ and $200-700^{\circ} \mathrm{C}$, respectively (Uzun, 2010). 


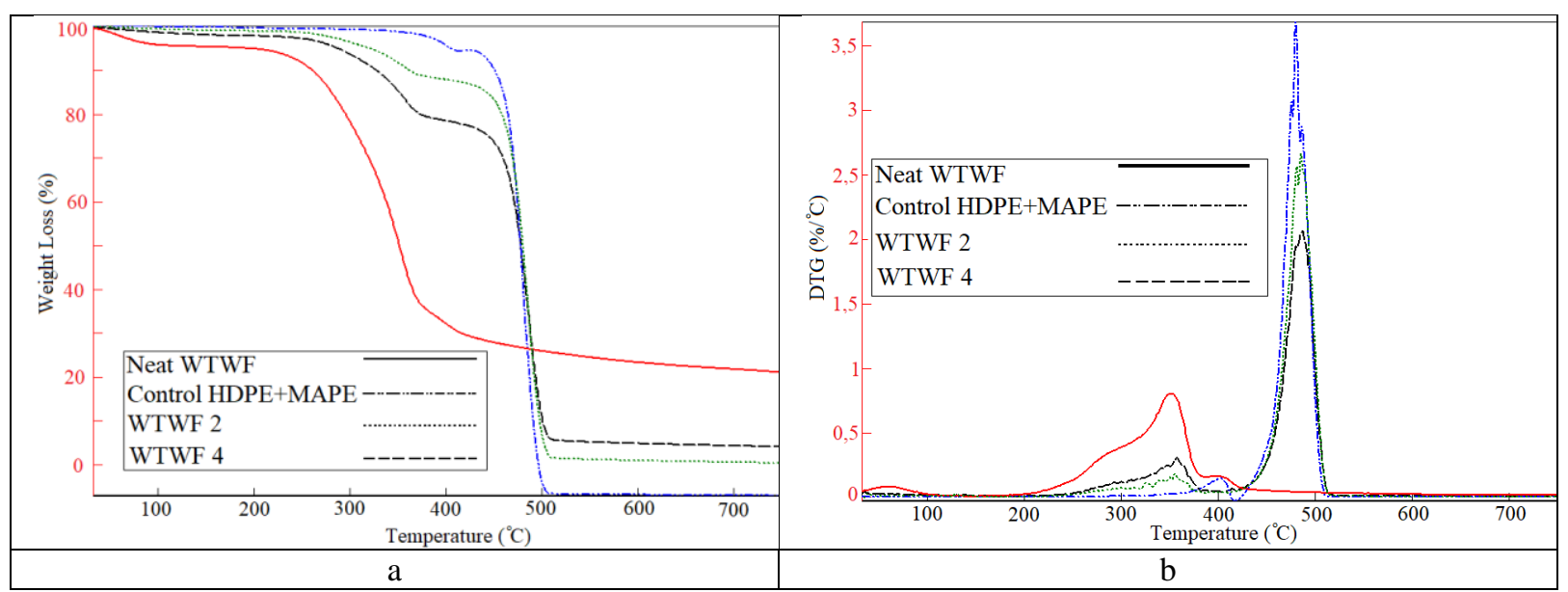

Figure 9: (a) TGA Thermographs of Neat WTWF, WTWF Filled HDPE+MAPE and Control (unfilled) HDPE+MAPE Thermoplastic Composites; (b) DTG Thermographs of Neat WTWF, WTWF Filled HDPE+MAPE and Control (unfilled) HDPE+MAPE Thermoplastic Composites

The highest residual weight was obtained from neat WTWF at $500^{\circ} \mathrm{C}$. The residual weight was increased with addition of WTWF in thermoplastic matrix. The previous studies also support this result (Mengeloglu and Kabakci, 2008; Yang et al., 2005; Kaboorani, 2010).

TGA thermographs of unfilled were similar to those of WTWF filled HDPE thermoplastic composite specimens.

Table 5: The Results of Thermogravimetric Analysis of WTWF and The Thermoplastic Composites

\begin{tabular}{|c|c|c|c|c|c|c|}
\hline \multirow{3}{*}{$\begin{array}{l}\text { ID } \\
\text { Control HDPE }\end{array}$} & \multirow{3}{*}{$\begin{array}{c}\begin{array}{c}\text { Onset } \\
\text { Temperature } \\
\left({ }^{\circ} \mathbf{C}\right)\end{array} \\
454\end{array}$} & \multicolumn{2}{|c|}{$\begin{array}{l}\text { Peak Temperature } \\
\qquad\left({ }^{\circ} \mathbf{C}\right)\end{array}$} & \multicolumn{2}{|c|}{ Weight Loss (\%) } & \multirow{3}{*}{$\begin{array}{c}\begin{array}{c}\text { Residue } \\
\text { after } \mathbf{5 0 0} \\
{ }^{\circ} \mathbf{C}(\%)\end{array} \\
3,92\end{array}$} \\
\hline & & \multicolumn{2}{|c|}{488} & \multicolumn{2}{|c|}{69,59} & \\
\hline & & $1^{\text {st }}$ peak & $2^{\text {nd }}$ peak & $1^{\text {st }}$ peak & $2^{\text {nd }}$ peak & \\
\hline Control HDPE+MAPE & 447 & 403 & 481 & 4,7 & 63,03 & 0 \\
\hline Neat WTWF & 185 & 354 & 400 & 52,31 & 67,76 & 25,96 \\
\hline WTWF 1 & 445 & 350 & 484 & 7,67 & 75,06 & 0 \\
\hline WTWF 2 & 446 & 356 & 490 & 9,10 & 74,31 & 6,44 \\
\hline WTWF 3 & 447 & 353 & 489 & 24,97 & 63,80 & 14,62 \\
\hline WTWF 4 & 447 & 359 & 490 & 16,96 & 73,37 & 9,90 \\
\hline
\end{tabular}

Figures 10 show the SEM micrographs of fractured surface of the manufactured composites. There is no significant difference between figures $10 \mathrm{a}$ and $10 \mathrm{~b}$. While a few WTWF particles and holes on fractured surface of $15 \mathrm{wt} \%$ WTWF filled samples (Figure 10c) occurred, WTWF particles and holes on fractured surface of $30 \mathrm{wt} \%$ WTWF filled samples (Figure 10e) increased. This result was due to the poor adhesion between not compatible WTWF (hydrophilic) and HDPE matrix (hydrophobic). However, addition of MAPE in matrix (Figure 10d and 10f) decreased this WTWF particles and holes on the fractured surface. 


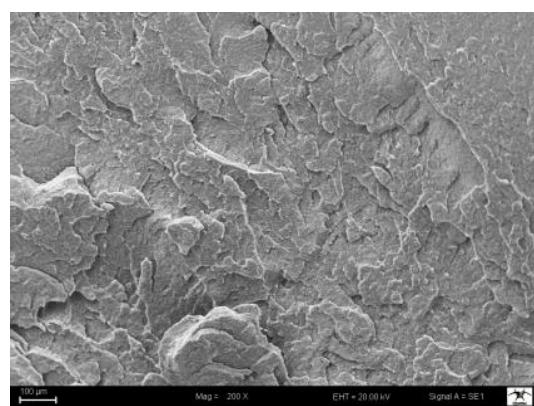

a

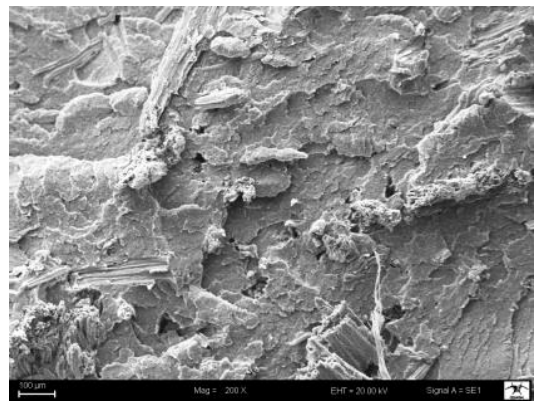

C

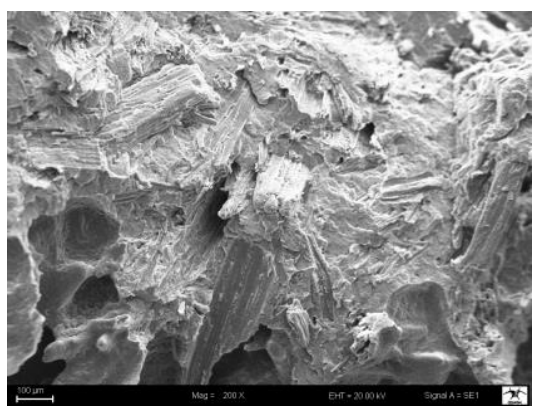

e

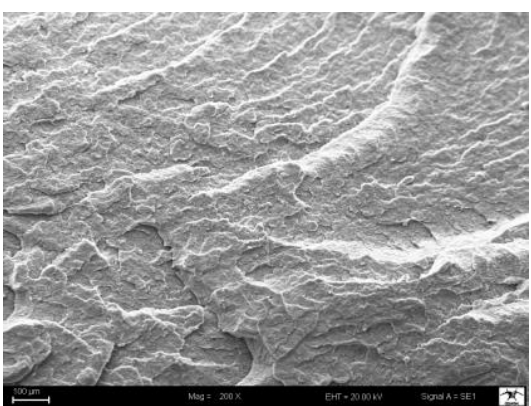

b

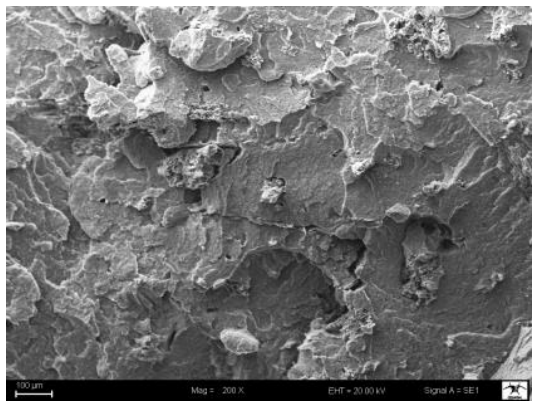

d

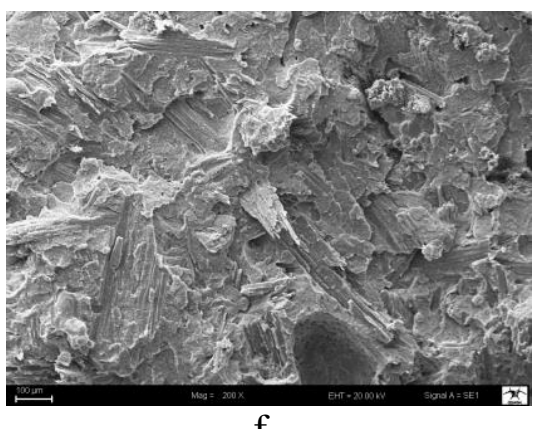

f

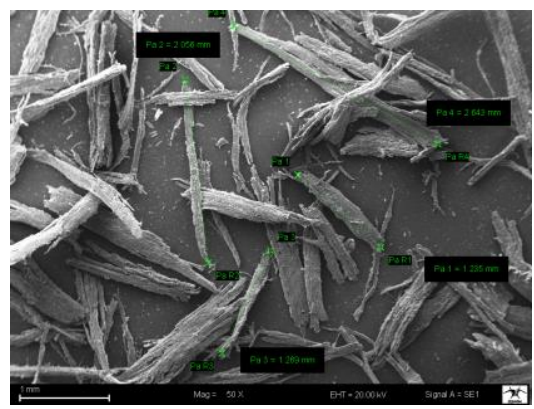

g

Figure 10: SEM Micrographs of : (a) HDPE, (b) HDPE + 3\% MAPE, (c) HDPE + 15\% WTWF, (d) HDPE + 15\% WTWF + 3\% MAPE, (e) HDPE + 30\% WTWF, (f) HDPE + 30\% WTWF $+3 \%$ MAPE, $(\mathrm{g})$ Waste Tea Wood Fibers. 


\section{CONCLUSION}

In this study, evaluation of WTWF as filler material for thermoplastic composites as an alternative to wood was investigated. Furthermore, effect of MAPE on properties of composites was determined. In the results of this study, density, tensile strength, tensile modulus, flexural strength and flexural modulus values of the composites increased by the rising of WTWF loading and addition of MAPE in the thermoplastic matrix. However elongation at break and impact strength values of the manufactured composites decreased by the rising of WTWF loading in the polymer matrix. Thermal properties of (15\%-30\%) WTWF filled HDPE composites had similar characteristics to those of unfilled HDPE thermoplastic composites. However, residual weight was increased with addition of WTWF in thermoplastic polymer matrix. WTWF particles and holes on the fractured surface of the samples were increased by the rising of WTWF loading in the matrix. This WTWF particles and holes on the fractured surface of the samples were seen less by addition of MAPE in matrix. The tested all samples provided the requirements of ASTM D 6662. It appears that WTWF can be potentially suitable raw materials for manufacturing thermoplastic composite products.

\section{ACKNOWLEDGMENT}

This study was supported by the Scientific Research Projects Coordination Unit of Kahramanmaraş Sütçü Imam University.

\section{AUTHOR CONTRIBUTIONS}

İlkay Atar: Designing the study, collecting data, analyzing data, analysis interpretation of the results, writing the article, İbrahim Halil Başboğa: Designing the study, data collection, Kadir Karakuş: Editing the article, Fatih Mengeloğlu: Analyzing data, analysis interpretation of the results, writing the article.

\section{REFERENCES}

ASTM 792-13 (2013). Standard Test Methods for density and specific gravity (Relativedensity) of Plastics by displacement. ASTM International, West Conshohocken, PA.

ASTM D 638 (2007). Standard Test Method for Tensile Properties of Plastics. ASTM International, West Conshohocken, PA.

ASTM D 790 (2007). Standard Test Method for Flexural Properties of Reinforced and Reinforced Plastics and Electrical Insulating Materials. ASTM International, West Conshohocken, PA.

ASTM D 256 (2007). Standard Test Method for Determining the Izod Pendulum Impact Resistance of Plastics. ASTM International, West Conshohocken, PA.

ASTM D 6662 Standard Specification for Polyolefin-Based Plastic Lumber Decking Boards ${ }^{1}$. ASTM International, West Conshohocken, PA. 
Chaharmahali, M., Mirbagheri, J., Tajvidi, M., Najafi, SK. \& Mirbagheri, Y. (2010). Mechanical and physical properties of wood-plastic composite panels. J Reinf Plast Comp. 29: 310-319.

Chan JH \& Balke ST. (1997). The thermal degradation kinetics of polypropylene: Part III. Thermogravimetric analyses. Polym Degrad Stabil 57: 135-149.

Coutinho, F.M.B., Costa, T.H.S. \& Carvalho, C.D.L., (1998). Effect of treatment and mixing conditions on mechanical properties. Polypropylene-wood fiber composites: J. Appl. Polym. Sci. 65, 1227- 1235.

Demir, H., Atikler, U., Balkose, D. \& Tihminlioglu, F. (2006). The effect of fiber surface treatments on the tensile and water sorption properties of polypropylene-luffa fiber composites. Compos Part A. 37: 447-456.

Kaboorani A.(2010). Effect of formulation design on thermal properties of wood/thermoplastic composites. J Compos Mater 44: 2205-2215.

Klyosov, AA. (2007). Wood-plastic composites, 1st ed. Wiley Interscience: Hoboken, New Jersey, USA

La Mantia FP, Morreale M \& Izhak ZA. (2005). Processing and mechanical properties of organic fillerpolypropylene composites. J Appl Polym Sci 96: 1906-1913.

Lai, S. (2003). Comparative study of maleated polyolefins as compatibilizers for polyethylene/wood flour composites. J. Appl. Polym. Sci. 87, 487-496; DOI 10.1002/app.11419.

Li, Q. \& Matuana, L.M. (2003). Effectiveness of maleated and acryclic acid-functionalized polyolefin coupling agents for HDPE-wood-flour composites. J. Thermoplast. Compos. 16, 551-564; DOI 10.1177/089270503033340.

Liu, H., Wu, Q. \& Zhang, Q. (2009). Preparation and properties of banana fiber-reinforced composites based on high density polyethylene (HDPE)/Nylon- 6 blends. Bioresource Technol. 100: 6088-6097.

Mengeloglu, F. \& Karakus, K. (2008). Polymer-composites from recycled high density polyethylene and waste lignocellulosic materials. Fresen Environ Bull. 17: 211-217.

Mengeloglu. F. \& Kabakci, A. (2008). Determination of thermal properties and morphology of eucalyptus wood residue filled high density polyethylene composites. Int J Mol Sci. 9: 107-119.

Mengeloglu, F., Matuana, LM. \& King, J. (2000). Effect of impact modifiers on properties of rigid PVC/ wood-fiber composites. J Vinyl Addit Techn. 6: 153-157.

Nunez AJ, Sturn PC, Kenny JM, Aranguren MI, Marcovich NE \& Reboredo MM. (2002). Mechanical characterization of polypropylene-wood flour composites. J Appl Polym Sci 88: 1420-1428.

Panthapulakkal, S. \& Sain, M. (2007). Agro-residue reinforced HDPE composites: Fibre characterization and analysis of composites properties. Compos Part A. 38: 14451454.

Sain M \& Panthapulakkal S. (2006). Bioprocess preparation of wheat straw fiber and characterization. Ind Crop Prod 23: 1-8.

Sombatsompop, N., Yotinwattanakumtorn, C. \& Thongpin, C. (2005). Influence of type and concentration of maleic anhydride grafted polypropylene and impact modifiers on mechanical properties of PP/Wood sawdust composites. J. Appl. Polym. Sci. 97, 475484; DOI 10.1002/app.21765.

Stark N \& Berger MJ. (1997). Effect of species and particle size on properties of wood-flourfilled polypropylene composites, In: Sypmosium of Functional Fillers for Thermoplastics and Thermosets, San Diego, California. pp.1-20. 
Stark, M. \& Rowlands, RE. (2003). Effects of wood fiber characteristics on mechanical properties of wood/polypropylene composites. Wood Fiber Sci. 35: 167-174.

Tea sector report (2019). General Directorate of Tea Enterprises. Taken from address https://www.caykur.gov.tr/Pages/Yayinlar/YayinDetay.aspx?ItemType=5\&ItemId=72 1 on 2 September 2021

Yang, H.S., Wolcott, M.P., Kim, H.S., Kim, S. \& Kim, H.J. (2007). Effect of different compatibilizing agents on the mechanical properties of lignocellulosic material filled polyethylene bio-composites. Compos. Struct. 79, 369-375; DOI 10.1016/j.compstruct.2006.02.016.

Yao, F., Wu, Q., Liu, H., Lei, Y. \& Zhou, D. (2011). Rice straw fiber reinforced high density polyethylene composite: Effect of coupled compatibilizating and toughening treatment. J Appl Polym Sci. 119: 2214-2222.

Wang, Y., Yeh, F.C., Lai, S.M., Chan, H.C. \& Shen, H.F. (2003). Effectiveness of functionalized polyolefins as compatibilizers for polyethylene/wood flour composites. Polym. Eng. Sci. 43(4), 933-945; DOI 10.1002/pen.10077. 